\title{
Which Roads (if any) to Social Investment? The Recalibration of EU Welfare States at the Crisis Crossroads (2000-2014)
}

\author{
STEFANO RONCHI \\ Research training group SOCLIFE, University of Cologne, Albertus-Magnus-Platz, 50923 \\ Cologne, Germany \\ email: ronchi@wiso.uni-koeln.de
}

\begin{abstract}
The social investment approach has been advocated as a blueprint for recasting European welfare states since the years of the Lisbon Strategy. After the Euro crisis squeezed the fiscal space available for welfare recalibration, the question has been raised as to whether social investment could withstand the economic turmoil. Relying on a new welfare expenditure dataset constructed from various Eurostat sources, this article looks at the budgetary recalibration of $27 \mathrm{EU}$ welfare states from the launch of the Lisbon Strategy to the aftermath of the Euro crisis (2000 to 2014). It compares the financial efforts that governments have put into social investment- and social protection-oriented policies, highlighting the different trajectories taken by EU welfare states at the crisis crossroads. Four scenarios for welfare recalibration are put forward, based on the social investment perspective and its critiques. The results show that the overall progress made by social investment in welfare budgets since 2000 came to a halt with the outbreak of the crisis. Bleaker scenarios materialised, whereas EU welfare states pursued retrenchment rather than investment, or had to face harsher budgetary trade-offs, expanding social investment to the detriment of social protection.
\end{abstract}

\section{Introduction}

The idea of social investment has influenced the debate on how to recast EU welfare states since the years of the Lisbon Strategy (Esping-Andersen et al., 2002). With the launch of the Social Investment Package in 2013, the European Commission explicitly endorsed this blueprint (European Commission, 2013a, 2013d). A so-called Social Compact followed, calling for a more effective and efficient use of welfare state budgets along the imperatives of social investment (European Commission, 2013c). Still, with the exception of Nordic countries, employment-centred social investment policies are poorly financed in the bulk of member states. 'Old' social protection programmes take the lion's share of social expenditure, leaving little space for investments in new social policies (Hudson and Kuhner, 2009; Nikolai, 2012).

In the aftershocks of the financial crisis, the question was raised as to whether the social investment strategy could withstand the economic turmoil 
(Van Kersbergen and Hemerijck, 2012). After the crisis began, austerity tightened the constraints on national economic policies, further reducing the budgetary space for welfare state recalibration. Although some general expansion of social investment spending was observed in the years prior to the Euro crisis (Vandenbroucke and Vleminckx, 2011; Kuitto, 2016), we know little about more recent developments. Today's context of scarcer resources potentially exacerbates the trade-off between spending for old protection-oriented and new investmentoriented programmes (Cantillon, 2011; Streeck and Mertens, 2011; Breunig and Busemeyer, 2012). Moreover, it makes it harder for those countries which had not invested in new policies before to catch up. There is no agreement on the trajectory taken by EU welfare states in the aftermath of the crisis. On one hand, some scholars argue that in most countries social investment has been pursued despite prima facie cost-containment policy priorities (Van Kersbergen et al., 2014). On the other hand, especially where austerity is biting harder, retrenchment rather than investment seems to be the rule (Petmesidou and Guillén, 2014), and worries about further divergence between EU welfare states have been raised (Kvist, 2013). Not all member states would have been able to afford the social investment strategy: at the crisis crossroads, some could have taken cheaper paths.

This article looks at how welfare state budgets were recalibrated in the EU-27 (all member states except Croatia) from the launch of the Lisbon Strategy in 2000 to 2014, through the crisis time. Building on the social investment perspective and its critiques, it develops four theoretical scenarios for the recalibration of welfare state budgets. The analysis is based on the Social Investment Welfare Expenditure (SIWE) data set (Ronchi, 2016): a new data set built on Eurostat sources, which provides a fine-grained disaggregation of social spending. Instead of looking at raw spending-over-the-GDP figures, the analysis relies on needsadjusted indicators of the effective 'budgetary effort' (spending per potential beneficiary) put into selected welfare programmes by governments. This allows us to track the progress of two fundamental dimensions of today's welfare states social investment and social protection - in public budgets. Did all member states increase resources over social investment-oriented programmes despite the tightened fiscal space? Were the investment and protection dimensions competing with each other into narrower welfare state budgets? Based on the trajectories of recalibration observed empirically, each member state is placed in one of the theoretical scenarios.

The results partly depart from previous findings that highlighted an expansion of social investment spending before the crisis (Vandenbroucke and Vleminckx, 2011; Kuitto, 2016). In the crisis aftermath, the general progress of social investment in public budgets came to a halt, and the fiscal trade-off between investment- and protection-oriented policies also became critical. This adds evidence to what has been pointed out in some recent policy reports (Bouget 
et al., 2015; Natali and Vanhercke, 2015): in most EU member states, social policy objectives seem to have been overwhelmed by fiscal consolidation. Overall, the economic crisis stands out as a critical juncture which has opened up bleaker prospects for the recalibration of EU welfare states.

The article is structured as follows. The next section reviews the literature on the social investment perspective applied to the analysis of welfare state budgets. We then outline the context of the Euro crisis, which the social investment strategy has to face. The fourth section draws four scenarios for welfare recalibration, based on different streams of literature. The SIWE data set and the methodology used for tracking budgetary welfare efforts are presented in the fifth section. The results section matches the empirical findings with the theoretical scenarios. The final section concludes by elaborating on both analytical and policy implications.

\section{Social investment and welfare state budgets}

The social investment perspective is becoming the most prominent key for understanding the ongoing change of advanced welfare states (Jenson, 2012). In its frame, the rationale of the new welfare state shifts from the sole protection of people from market risks, to their empowerment within the market. The former objective is served by long-established social programmes such as unemployment benefits and pensions; cash benefits whose aim is to compensate those out of work for some kind of income loss. By contrast, a new wave of social policies has emerged, which serves a different aim: that of preparing and enhancing human capital through all stages of the life course, fostering labour market participation and addressing new social risks (Taylor-Gooby, 2004). Public investments in daycare services, active labour market policies (ALMP), education and training, follow this logic. As such, they are generally considered to be social investment-oriented policies (Morel et al., 2012). According to the advocates of social investment, a balanced mix of the two dimensions - protection and investment - is the key to building a new welfare state capable of keeping up with today's economic and social challenges (Esping-Andersen et al., 2002; Hemerijck, 2013).

The social investment approach has also served as an analytical tool for gauging welfare state change. Large- $\mathrm{N}$ comparative studies have mostly focused on the structure of social expenditure, differentiating between spending for 'old', 'compensatory' social protection, and spending for 'new', investment-oriented policies (Vandenbroucke and Vleminckx, 2011; Nikolai, 2012; Vaalavuo, 2013; Hemerijck, 2013; Van Vliet and Wang, 2015; Kuitto, 2016). Vandenbroucke and Vleminckx (2011) showed that, overall, social investment spending increased across OECD countries from the late 1980 os to the pre-crisis years. ${ }^{1}$ The general trend, however, conceals wide differences across countries. EU member states are 
not equally placed with respect to the social investment-orientation of their welfare states (Nikolai, 2012). Although there is some blurring, the welfare regimes developed since the work of Esping-Andersen (1990) still help to define the different spending profiles of European welfare states (Kuitto, 2016). Nordic countries fall closer to the ideal type of social investment, being big spenders on both protection- and investment-oriented policies (Huo et al., 2008; Hemerijck, 2013). Other member states offer a more mixed picture. Liberal welfare states have favoured the development of some investment-oriented policies (e.g. activation, education and training) over that of social protection, which remains comparatively weak (Nikolai, 2012; see also Deeming and Smyth's [2015] considerations on the liberal 'light' social investment strategy). The opposite is true for continental EU countries, where spending is biased towards social protection, and the budgetary space available for social investment is tighter (Nikolai, 2012). Nevertheless, recent reforms in the domains of ALMP and daycare services have progressively paved the way for elements of social investment (Van Kersbergen and Hemerijck, 2012). Southern and Eastern European welfare states stand out as laggards, performing worse both in terms of financing of social investment-oriented programmes (Nikolai, 2012) and in terms of human capital and social outcomes (Kvist, 2013).

The expenditure-based approach to the analysis of social investment also helped to highlight the budgetary trade-offs that are likely to emerge in times of harsh fiscal constraints. During the years of the Lisbon Strategy, poverty levels stagnated in spite of the growth of employment. Among the possible explanations for this puzzle, the so-called 'resource competition' hypothesis refers directly to a trade-off in welfare state budgets (Cantillon, 2011; Vandenbroucke and Vleminckx, 2011). According to this hypothesis, given scarce resources, the stress put on employment-centred social investments in the Lisbon years implied cutting spending for social protection policies, which are deemed to be more redistributive (although they are not necessarily so in all policy domains: see Vaalavuo, 2013). Vandenbroucke and Vleminckx's (2011) findings did not support the resource competition hypothesis. Although the share of public budget taken by social investment-oriented programmes increased, it remained still too residual to crowd out social protection spending, which also kept on growing. ${ }^{2}$

Streeck and Mertens (2011) took an opposite view of the same budgetary trade-off. Their work revealed a decreased capacity of governments to shift resources at all towards social investments in times of harsh fiscal pressure (see also Mertens, 2017). To some extent, this reverses the resource competition hypothesis: it is what they called 'mandatory' spending (i.e. the payment of vested social protection benefits such as pensions) that tends to crowd out 'discretionary' social investments. Through a more fine-grained multivariate analysis, Breunig and Busemeyer (2012) also came to the conclusion that in times of austerity social investment spending is hit harder than social protection spending. 


\section{Social investment and the Euro crisis}

The outbreak of the Euro crisis further tightened the fiscal constraints on welfare state budgets. As the contagion from the US subprime mortgage crisis crossed the Atlantic, most EU member states first reacted in an expansionary fashion, increasing social expenditure to match the augmented unemployment (Armingeon, 2012). With the outburst of the Greek crisis in late 2009, what had started as a financial-sector crisis was then perceived as a sovereign-debt crisis. This marked the shift from (mildly) counter-cyclical policies to fiscal austerity, to an extent that exceeded that of previous recessions (European Commission, 2013b). Welfare expenditure as a whole, and not only social investment, became more vulnerable to retrenchment. Although social investment-oriented programmes appear as easier, less-visible targets for cutbacks, they make up a very small part of the budget. Reducing social investment expenditure (or preventing its expansion) has a much smaller effect on reducing the deficits that exploded as a consequence of bailing out the banks, compared with reducing the generosity of bigger programmes such as pensions or unemployment benefits. Long-established social entitlements, considered no longer sustainable, were increasingly targeted for retrenchment.

The fiscal strain of austerity has not been the only pressure to which European welfare states have been exposed in the crisis aftermath. An opposite push came from the social investment strategy promoted by the EU. Taking on the challenge of making 'long-term social investment and short-term fiscal consolidation mutually supportive at both the EU level and in the Member States' (Vandenbroucke et al., 2011), the social investment strategy indeed represents an appealing blueprint to help European welfare states pass the crisis stress test. After a long path, starting with the Lisbon Strategy and boosted by academic advocacy (Esping-Andersen et al., 2002; Vandenbroucke et al., 2011), the European Commission launched the Social Investment Package for Growth and Cohesion in 2013, making explicit the EU's endorsement of this blueprint (European Commission, 2013d).

But can such a policy strategy survive the crisis aftershocks? Austerity seems to have seriously hindered the progress of social investment (Bouget et al., 2015; Natali and Vanhercke, 2015). However, recent empirical studies reported contrasting findings. On one side, some highlighted that, at least in northern and continental Europe, welfare states kept moving towards social investment in spite of the prima facie priority given to cost-containment policies (Van Kersbergen et al., 2014). On the other side, the progress of social investment seemed overwhelmed by austerity and retrenchment, especially in the crisisridden peripheries of the EU (Kvist, 2013; Petmesidou and Guillén, 2014; Pavolini et al., 2015). Darker views have gone even further. For example, Pierson (2011: 21; emphasis added) has raised a question on whether 'the real era of retrenchment' has finally begun. Should this be the case, not only would social investments find 
no fiscal leeway to develop, but all welfare spending would be irreversibly rolled back. That is, the demise of the welfare state instead of its transformation and relaunch (see also Armingeon, 2013).

\section{Four scenarios for budgetary welfare recalibration}

At the crisis crossroads, European welfare states are cross-pressured by two forces: the social investment strategy on the one hand, and austerity on the other. At first sight, two routes seem possible. The crisis could open an unprecedented window of opportunity for social and economic reforms (Diamond and Liddle, 2012: 286), whose 'high way' is indicated by the social investment strategy. Otherwise, welfare states under strain could give up in the face of mounting pressures for retrenchment.

Based on the budgetary trade-offs outlined above, a closer inspection goes beyond such a black-and-white picture. As done in previous research (see section 'Social investment and welfare states budgets'), we dissect countries' social budgets, differentiating between the expenditure for social protection- and social investment-oriented programmes. The former are cash benefits which provide income compensation for old industrial social risks. The latter are investments in services, aimed at enhancing human capital and labour market participation, and addressing the new social risks that have emerged in post-industrial societies. By crossing these two fundamental dimensions of the new welfare state, we get a better understanding of all possible trajectories viable for welfare recalibration. Countries can either increase or decrease the budgetary effort they put into each of the two dimensions. This gives four possible scenarios for the budgetary recalibration of European welfare states, as shown in Table 1.

The four scenarios provide an analytical framework for interpreting welfare state change. Each of them matches with different normative views and theoretical expectations that have been proposed in the literature. In the top-right quadrant, the resources put into both welfare state dimensions (social protection and social investment) are increased: a positive-sum solution which we call the 'high road to social investment' (scenario 1). In the view of its advocates, an ideal turn to social investment arguably occurs when governments increase the effort they put into social investment more than into social protection, shifting the balance from compensatory cash benefits to preventative investments (Hemerijck, 2013). In a context of scarce financial resources, the expansion of social investmentoriented policies could nevertheless take all the fiscal space available, crowding out spending for 'costly' social protection functions such as unemployment benefits. This is depicted in the bottom-right quadrant of Table 1 (scenario 2) and reflects the trade-off highlighted in the 'resource competition' hypothesis (Cantillon, 2011; Vandenbroucke and Vlaminckx, 2011): the budgetary effort on social investment again increases, but that on social protection falls. The opposite 
TABLE 1. Four scenarios for the budgetary recalibration of European welfare states

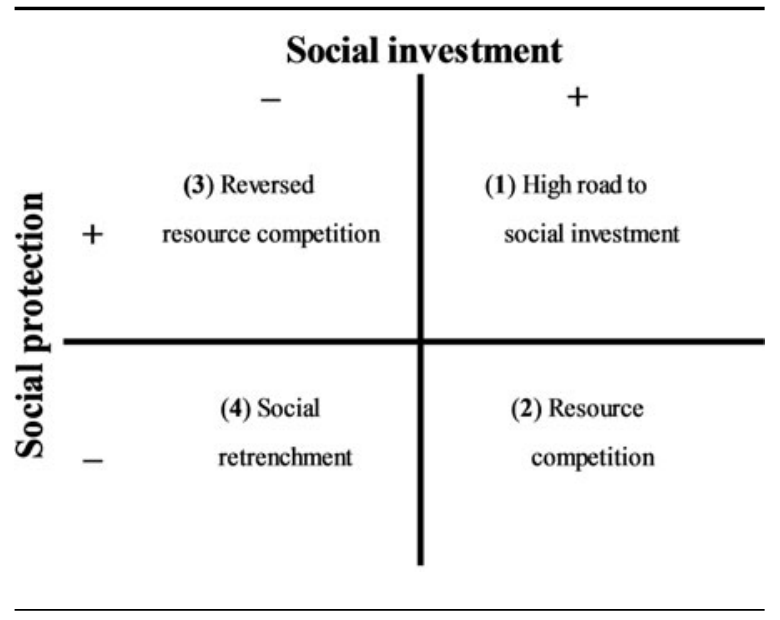

is true in the top-left quadrant: the 'reversed resource competition' scenario (3). Here it is the budgetary effort put into social protection that increases, to the detriment of social investments. Given tight budget constraints, the financial weight of enduring policy legacies (welfare entitlements politically anchored in vested interests) could leave no room for investing in new policies (Streeck and Mertens, 2011; Breunig and Busemeyer, 2012). Last, we find the scenario of 'social retrenchment' (4), in which both social investment and social protection are rolled back. This latter scenario matches with the darkest view about a real age of austerity which is just getting started now, with the Great Recession (Pierson, 2011; Armingeon, 2013).

\section{Data and methodology}

\section{The skeleton of social investment revisited}

To frame it as De Deken (2014) did, this article maps 'the skeleton of the social investment welfare state' in public budgets. ${ }^{3}$ Previous research highlighted the usefulness of disaggregating total welfare expenditure into separate functions, which were found to be determined by different politico-institutional factors and in turn associated with different socio-economic outcomes (Castles, 2009; Van Vliet and Wang, 2015). Many empirical studies have re-aggregated social spending categories to fit the social investment perspective (see the two previous sections), bringing new empirical and analytical insight to our knowledge of the social investment welfare state.

The expenditure-based approach has pros and cons (a critical review is provided by De Deken, 2014), and some limitations are unavoidable. A first 
limitation regards the general question of how to measure welfare state change (Clasen and Siegel, 2007). By looking at spending data, researchers can only grasp the budgetary weight of social policies but not the institutional characteristics of such programmes. It is, however, exactly the cost of social policies that gains political salience in times of fiscal consolidation (Mertens, 2017), bringing to light the budgetary trade-offs that are a crucial focus of this article. A second limitation is specific to the operationalisation of social investment through social expenditure. The distinction between 'social investment' and 'social protection' spending items is often blurred; many policies in fact serve both aims (De Deken, 2014; Nolan, 2013). ${ }^{4}$ The uncertain categorisation of social programmes largely derives from the same conceptual ambiguity of social investment: a strong point for policy-makers who use it as a political platform (Jenson, 2017: 4), but a hurdle for researchers interested in using it as analytical framework (Nolan, 2013). Given this (intentional) ambiguity, any agreement on a fixed operationalisation will hardly ever be reached.

Aware of its shortcomings, my analysis builds on the disaggregated expenditure approach. The proposed methodology differs from the bulk of those used previously in two respects: the choice of the data source and the (expanded) allocation of social spending functions over the two welfare dimensions. While most studies of social investment spending have relied on the OECD Social Expenditure Database (SOCX), my methodological effort builds on expenditure data from various Eurostat sources, as provided in the SIWE data set (Ronchi, 2016). ${ }^{5}$ Eurostat sources include: the European System of integrated Social PROtection Statistics (ESSPROS), Eurostat Labour Market Policy (LMP) statistics, and Eurostat data on education and research and development (R\&D). The SIWE data cover all member states except Croatia (instead of 21 member states included in OECD-SOCX) and provide more complete time series for the time span considered in this article. In spite of some differences in data collection (see Adema and Ladaique, 2009), the degree of disaggregation reached by Eurostat is comparable to that of OECD-SOCX. As done in previous contributions, we take into account gross public expenditure: data on net spending do not reach such a fine-grained level of disaggregation. ${ }^{6}$

As for the allocation of social spending functions over distinct welfare dimensions, we also use the heuristic dichotomy which differentiates between social protection spending and social investment spending (hereafter SP and SI). Nevertheless, we modify and expand the expenditure-based methodology. Previous studies have mostly categorised spending items based on the rationale of different policies. However, policies can follow multiple rationales (De Deken, 2014; see note 4): this leads to ample margins of discretion when allocating items to welfare dimensions. Hence, we differentiate between SP and SI by looking at the way in which different programmes are provided: cash benefits are considered as SP, benefits in kind (services) as SI. This grants a more objective criterion 
without neglecting the policy rationale aspect: cash benefits in fact provide ex-post-compensation for 'old' risks (hence, a social protection rationale), while investment-oriented policies generally come as services (Ahn and Kim, 2015).

As shown in Appendix 1 (see Supplementary material), SP includes passive labour market policies (PLMP), cash benefits for families with children and oldage benefits. ALMP, care services for families with children and for the aged, public spending for education (from primary to post-secondary non-tertiary) and research and development $(\mathrm{R} \& \mathrm{D})$ are counted in SI. This categorisation departs from the bulk of previous studies in three ways: (1) Contrary to what is usually done, healthcare spending is not incorporated in the SP dimension: we exclude it from the dichotomy. Healthcare is a very ambiguous welfare function that does not exclusively fit either of the two categories suggested. As opposed to the rest of the SP functions, healthcare is generally not based on cash transfers but on the provision of services that both compensate for the occurrence of health problems, and (re-)capacitate those in need. Hence, the dual protection-investment aim appears especially marked here. Moreover, in the case of healthcare, expenditure is a particularly bad indicator of government effort (see e.g. Wilkerson, 2003). (2) Following Streeck and Mertens (2011) and Beramendi and his colleagues (2015), I expand the SI dimension by including public spending for $\mathrm{R} \& \mathrm{D}$. Investing in $\mathrm{R} \& \mathrm{D}$ is in fact part and parcel of a SI strategy centred on human capital in a knowledge-based economy, and was among the targets of the Lisbon Strategy. (3) The categorisation of parental leave policies as either SI or SP is a contested issue (De Deken, 2014). Although I classify them as SP (insofar as they consist of cash benefits), considering them as SI did not alter the findings shown in the results section below.

\section{Country sample and time span}

The recalibration of welfare state budgets is observed for all EU-27 countries (Croatia is excluded due to missing values). Countries are grouped into the most commonly used clusters (for a review, see Ferragina and Seeleib-Kaiser, 2011). Welfare regimes are used as a reference point to indicate the different policy legacies which exist across the EU. That is, the institutional 'starting blocks' of very different member states now called to embark on the road to social investment.

The time span observed in this study is 2000-2014. The analysis first compares the average levels for the years 2000-2008 with those for the aftermath of the crisis (2009-2014), and then narrows the focus to the post-crisis dynamics only. 2009 is taken as the watershed year between the period of overall economic growth of the early 2000 s and the crisis 'rainy days'. ' After 2009, the bulk of EU countries shifted to pro-cyclical fiscal policies (European Commission, 2013b). Fiscal austerity could in fact have drastically altered the budgetary trends observed in the early days of the Lisbon Strategy. 


\section{Budgetary welfare effort}

We focus on the levels and changes of 'budgetary welfare effort' (BWE): a measure of the effective financial effort that governments put into the two highlighted dimensions of the welfare state. Raw figures on welfare expenditure over the GDP are not very explanatory in this respect. Both the numerator and denominator are susceptible to economic downturns as well as to the demographic structure of (ageing) populations; contextual factors that have nothing to do with the actual government effort. ${ }^{8}$ Therefore, we analyse social expenditure trends in volumes, expressed in purchasing power standard (PPS) for the EU-28 at constant prices (base year: 2005), and weighted for the target population of the selected social programmes. This adjusts expenditures for the extent of the respective social needs in a given country-year. For each welfare function, the BWE comes net of distortions due to fluctuations of the business cycle or of the structure and the needs of the population. The general formula for the construction of BWE indicators is the following:

$$
B W E=\frac{\text { Euros spent on a given welfare function }}{\text { target population of that given function }}
$$

The formula tells us how many Euros (in PPS) a country spends on average per potential beneficiary for a given welfare function. ${ }^{9}$ The target populations used in the calculation are the unemployed population for working-age functions (labour market programmes), and the respective population sub-groups for the other welfare functions ( $0-4$ years for family/children programmes, 5-19 years for education, over 64 years for old-age programmes, and the total population for $\mathrm{R} \& \mathrm{D}$, since the latter is expected to produce economies of scale benefiting the whole community).

Two composite indices for SP and SI are finally computed taking the standardised mean scores of the BWE indicators for the functions included in each of the two welfare dimensions. The mean and standard deviation used for the standardisation are obtained from the full sample, pooling all country-years.

\section{Results: welfare state budgets in motion}

Based on the trends of the two composite BWE indices for SP and SI introduced above, this section places EU welfare states in the scenarios for welfare recalibration. The detailed trends that underlie the following figures are found in Appendix 2 (see Supplementary material), which also shows the BWEs for each policy field composing the SI and SP indices. Figure 1 plots member states according to their crossed SI and SP scores. The markers indicate the average pre-crisis BWE scores (2000-2008), and the arrows indicate the change from the pre-crisis to the post-crisis average (2009-2014). 


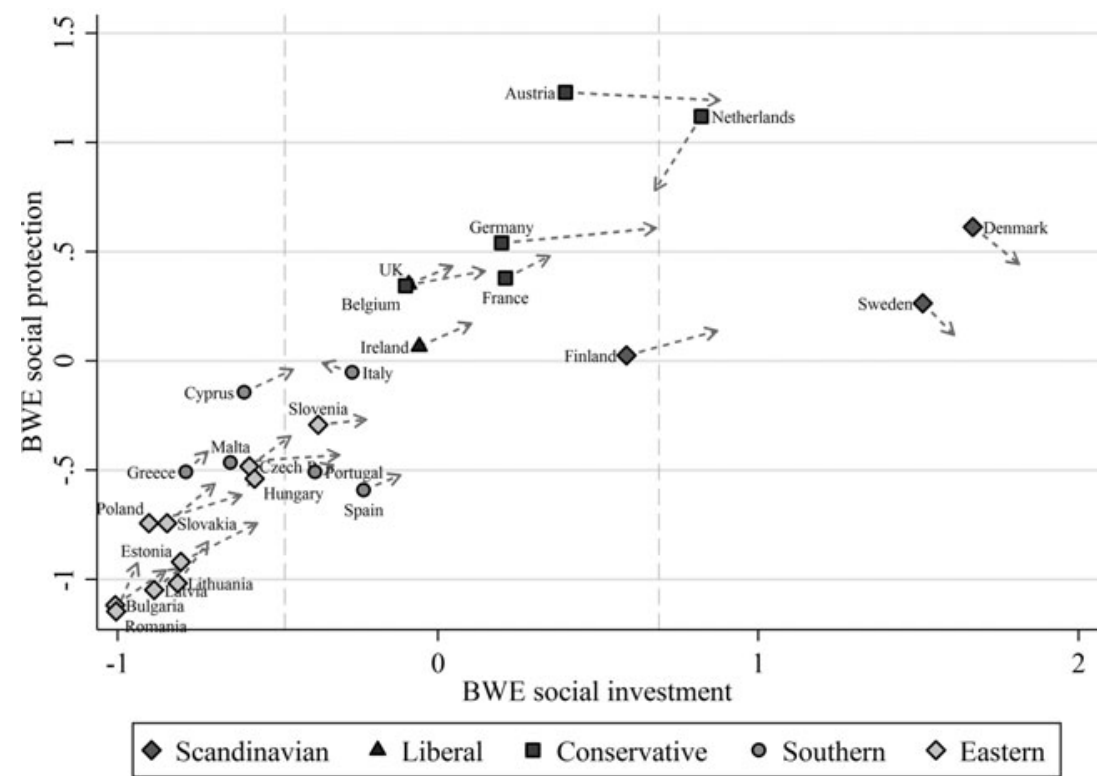

Figure 1. Budgetary Welfare Efforts: pre-crisis levels and directions of change.

Let us first look at the pre-crisis levels. EU countries seem to align with a positive linear correlation: more generous welfare states that score higher on SP also score higher on SI. The dashed vertical lines mark the limits of three clusters obtained through a simple hierarchical cluster analysis (Ward's linkage method) conducted on the single BWE-SI variable for the pre-crisis averages. Although welfare regimes 'still feature differing spending profiles with respect to both the relation of social investment and social [protection] measures' (Kuitto, 2016: 452), they appear to be a bit blurred here. The blurring is in line with previous research based on raw expenditure-over-GDP data, which pointed out that since the mid-200os - 'traditional regime analysis no longer represent[ed] a valid framework for contemporary analysis' (Nikolai, 2012: 110). This depends on the different perspective from which we look at the welfare state. While EspingAndersen's (1990) traditional clusters were based on the generosity of social insurance programmes, the expenditure-based approach loses some information on the institutional characteristics of cash benefits, but adds variation along another dimension which has become increasingly relevant: that of SI, which not always perfectly matches the welfare generosity profile.

Denmark and Sweden stand out as champions of SI. The other socialdemocratic country - Finland - falls closer to the conservative block. By contrast, the Netherlands places itself in the high-SI cluster, although with higher SP scores. Austria follows the Netherlands very closely. A scattered picture emerges in the middle part of the plot, where liberal and the remaining conservative welfare 
states are mixed, followed soon after by the bigger Southern welfare states (Italy, Spain and Portugal) and Slovenia. The bottom-left part of the plot includes the rest of the SI laggards: the remaining Southern countries and the new Eastern member states; the latter with the lowest scores on both dimensions.

The arrows in Figure 1 indicate the direction of change: the shift from the preto the post-crisis average scores. Almost all arrows point towards an expansion of the BWE, especially in the direction of SI. However, starting levels seem to matter. With the exception of Italy, Southern and Eastern laggards seem to be undergoing a (moderate) catch-up process on both SI and SP. The more spectacular catch-ups are nevertheless found among those welfare states that already fall closer to the SI champions. Austria, Germany and Finland have reduced the gap in the SI score with Denmark and Sweden. By contrast, the Netherlands seems to have gone against the tide, retrenching 'from above'. Although starting from comparatively very high levels, it decreased the BWE on both SI and SP.

Figure 2(a) presents the changes, plotting the countries according to the difference between post- and pre-crisis average BWE scores. This allows a direct match of member states with the scenarios presented in Table 1. Over the whole period examined (2000-2014), almost all member states successfully increased their BWE put into SI. This matches Kuitto's (2016) observation with regards to pre-crisis spending-over-the-GDP trends. Most countries place themselves in the 'high road' scenario (1), having increased BWE on both welfare dimensions (although to different degrees). The second scenario includes countries in which gains in the budgetary effort on SI have been achieved to the detriment of SP - the 'resource competition scenario' (2). The progress of SI seems to have partly crowded out SP only in the cases of Sweden, Denmark and - to a lesser extent - Austria. However, it has to be noted that all countries that reduced their budgetary effort in SP (those below the $\mathrm{x}$-axis) did so starting from comparatively high levels. In a way, they seem to have reached a sort of upper bound for SP. Despite the direction taken, their welfare states are still among the most generous in terms of SP. Alone in the scenario of 'reversed resource competition' (3), Italy behaved the other way around, increasing its effort into SP while reducing its effort into SI. Indeed, the literature refers to Italy as the exception in the European SI framework, with a welfare legacy biased towards SP, and no progress made in SI during the Lisbon years (Hemerijck, 2013: 264; León and Pavolini, 2014). The Netherlands stands out in the 'social retrenchment' scenario (4). By and large, this reflects Van Kersbergen et al.'s (2014) considerations of the retrenchment component which has characterised recent Dutch welfare reforms. As stressed above, starting levels matter: the Netherlands remains in any case one of the most generous and SI-oriented welfare states.

In the light of the austerity turn that followed the Euro crisis, the positive picture which emerges when comparing average pre-crisis to post-crisis levels can however be overly optimistic. The catch-up process that many member states 
(a) PRE-POST CRISIS: difference between mean levels after (2009-14) and before (2000-08) the crisis

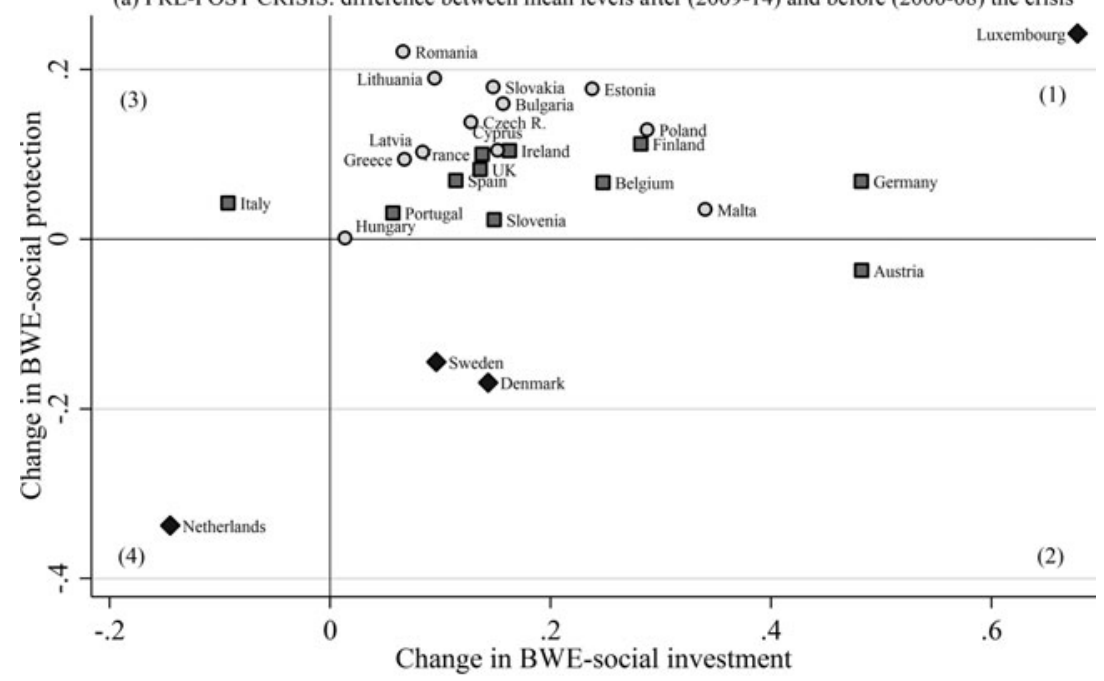

(b) POST-CRISIS ONLY: difference between levels in 2014 and 2009



$\circ$ Low social investment $\square$ Medium social investment $\diamond$ High social investment

Figure 2. Member States placed into the four scenarios. Based on: (a) the change from the launch of the Lisbon Strategy to the crisis aftermath; (b) the post-crisis change only.

undertook during the Lisbon years could have slowed down after the crisis, and budgetary trade-offs worsened: an aspect that we cannot grasp from Figure 2 a. To unveil the crisis aftershocks, we narrow the focus to the post-crisis period only. Figure $2 \mathrm{~b}$ places member states into the same scenarios mentioned above, but this time their positions are based on changes in BWE from 2009 to 2014. 
After 2009, the growth in BWE on both SP and SI came to a halt, and even reversed in some countries. With the exception of Denmark, all countries slipped towards the scenarios of resource competition (2) and social retrenchment (4). While in the Lisbon years only the most generous welfare states reduced their effort in the SP dimension (Figure 2a), retrenching SP became the rule after the crisis, regardless of starting levels. To some extent, this comes as no surprise. Even though they are protected by vested interests which make their retrenchment politically difficult (Streeck and Mertens, 2011), SP programmes take the largest share of public budgets. As such, they became the primary target for reducing the deficits that exploded during the financial crisis. Especially in the crisisridden peripheries of the EU, budget constraints became tighter after the crisis. As evident in Figure 2b, austerity not only made it harder to invest in new policies but it also directly hit established SP programmes (Petmesidou and Guillén, 2014; Natali and Vanhercke, 2015; Pavolini et al., 2015).

The most worrying signal for the SI strategy is the presence of eleven countries in the bottom-left quadrant of Figure $2 \mathrm{~b}$; eleven countries in which the effort on both SP and SI was rolled back. In the crisis aftermath, social retrenchment rather than investment became an option. Where governments continued instead to expand their BWE on SI, budgetary trade-offs became unavoidable ( see the 12 countries in the bottom-right quadrant of Figure $2 \mathrm{~b}$ ). In the post-crisis context of harsher fiscal consolidation, mild expansions of (less costly) SI programmes had to happen to the detriment of the SP programmes, which resulted in reduced budgetary effort.

The worries concerning resource competition are confirmed by Figure 3, which shows the average BWE trends of SI and SP for the whole EU-27. The synthetic indices have been recomputed taking the year 2000 as a baseline (i.e. the mean and standard deviation for the standardisation are those of 2000 , fixed, so as to track the average over-time trends). This clearly shows that, while SP kept pace with the budgetary expansion of SI up to the crisis outbreak, the picture drastically changed after 2009. On average, the progress of SI slowed down considerably, almost stagnating. Meanwhile, that of SP plummeted: the (average) gap between the two welfare dimensions increased, reflecting the resource competition pattern that materialised in many countries.

\section{Conclusion and discussion}

According to a growing academic advocacy, the social investment strategy should serve to overcome the fiscal pressures put by the crisis on European welfare states, reconciling today's economic and social urgencies (Vandenbroucke et al., 2011). However, not all European welfare states are placed on the same starting blocks. Notably, while Nordic countries fall close to the ideal type of the SI welfare state, other member states (especially Southern and Eastern) lag behind with 


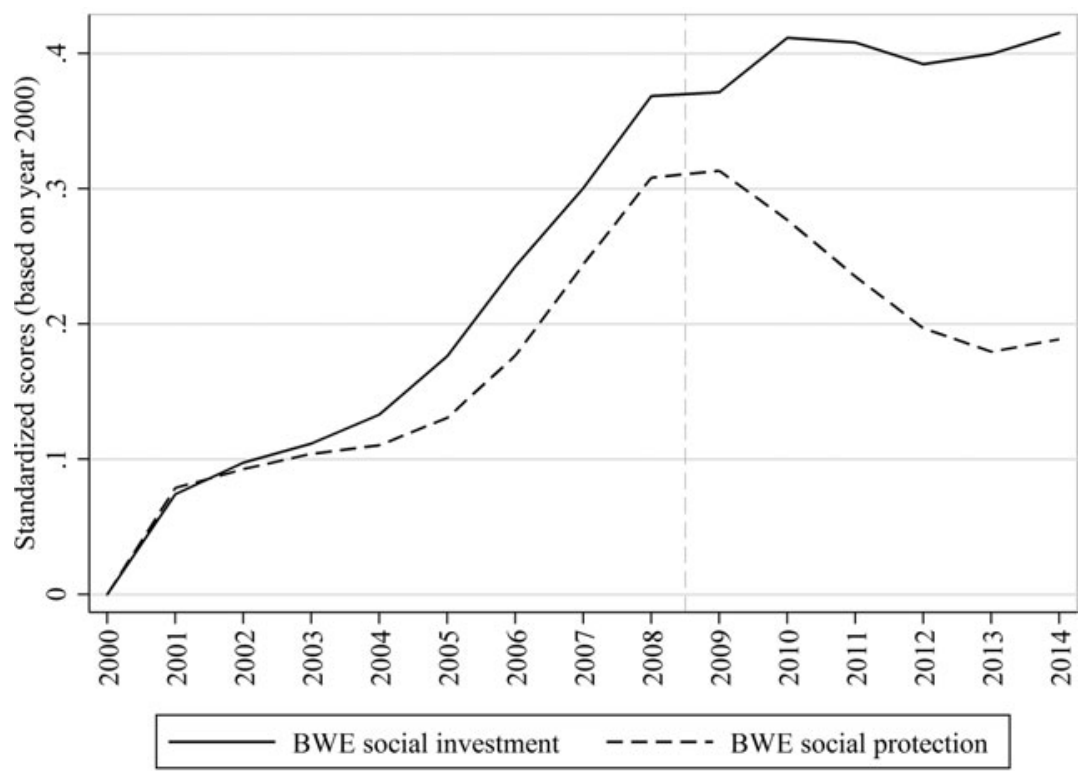

Figure 3. Average trends of Budgetary Welfare Efforts on SI and SP for the EU-27 $(2000=0)$.

respect to many dimensions. The Great Recession has then come to threaten the fiscal viability of SI: after the Euro crisis broke, austerity carried the day, further constraining social budgets. Based on Eurostat data, and on a finegrained measure of needs-adjusted budgetary effort, this article has assessed the trajectories taken by the recalibration of EU welfare states from the launch of the Lisbon Strategy to the crisis aftermath (2000-2014).

The results show that the crisis has indeed put the brake on the progress that SI had made in member states' social budgets during the Lisbon years. This contrasts with the positive pattern highlighted by previous studies, which focused on data preceding the Euro crisis aftershocks (Vandenbroucke and Vleminckx, 2011; Hemerijck, 2013; Kuitto, 2016). On the other hand, the results that have emerged in this article are in line with the conclusions reached by recent qualitative policy analyses on social investment and welfare reforms in the EU (Petmesidou and Guillén, 2014; Bouget et al., 2015; Natali and Vanhercke, 2015). Still, as testified by the position of most EU countries in the 'high road to SI' scenario in Figure $2 \mathrm{a}$, in the great majority of member states the budgetary progress made since the outset of the Lisbon Strategy has not been jeopardised, at least up to 2014. That is, the crisis has brought a widespread slowdown of the budgetary progress of SI, but not (yet) a U-turn.

However, contrary to what seemed to be the case before the crisis (Vandenbroucke and Vleminckx, 2011), resource competition has become a matter of concern during the crisis aftershocks. This poses a politically salient trade-off for governments, whose room for manoeuvre has further tightened 
over recent years. Politicians interested in expansionary welfare recalibration for electoral reasons would most likely have to choose either to expand the protectionor the investment-oriented policy dimension, but not both. When pursued at all, a budgetary expansion of SI in the context of post-crisis austerity appears possible only while retrenching SP, which comes at an electoral cost. Whether this is just a temporary shock or the start of a 'real age of austerity' (Pierson, 2011) remains to be seen. To date, it seems at least reasonable to raise doubts about the budgetary viability of what we called 'the high road to social investment' for crisis-ridden countries.

Some considerations arise with regards to the dynamics of EU welfare states' change. When looking at both levels and the change of budgetary welfare efforts (spending in volumes per potential beneficiary), traditional welfare state regimes get more nuanced. Different welfare legacies do not seem to channel social budgets into predetermined tracks. A catch-up process is underway on the SI dimension, although it is more pronounced in the better-placed continental economies (e.g. Germany and Austria), whose distance from the Nordic champions of SI was less marked from the beginning.

From an analytical point of view, the SI perspective, together with its critiques, has provided useful tools for looking at welfare state change. The scenarios we have built for interpreting our empirical findings offer an analytical framework that can also be useful for further research to identify different trajectories of welfare recalibration, and to ground them theoretically in the literature. The wide variation in the placement of different countries into different scenarios suggests the presence of a multitude of factors behind welfare state change. Unveiling the institutional, political and economic determinants of SI will be a crucial task for future contributions. Moreover, the overall trends of SI and SP shown here conceal variation in the trajectories taken by different policy fields. For example, increases in the budgetary effort put into the general SP dimension often conceal retrenchment of working-age protection policies (i.e. a decrease of the BWE indicator for the working-age function: see Appendix 2 in the supplementary material). Research on specific policy fields can sharpen our understanding of the development of different SI strategies.

This article focused on the budgetary side of SI; one side of a multi-faceted variable. The question is then whether, in a context of budgetary disinvestment, SI could flourish anyway and deliver the wished-for socio-economic outcomes. This depends not only upon a successful recalibration of social budgets but also on a more efficient use of the (scarcer) resources deployed, as well as on the institutional and economic context of member states that differ greatly from each other. The challenge of the SI strategy gets arguably harder to take up, especially for those countries which have not invested in new social policies so far, and are now facing adverse economic conditions. Based on the findings in this article, we cannot exclude the possibility that, while better-off countries will keep to the 
well-trodden 'high road', those that had just started to catch up during the Lisbon years will stop or even reverse their progress, having no fiscal leeway to pursue SI at all, or opting for a lighter variant in which SP is left behind (cf. Deeming and Smyth, 2015).

\section{Supplementary material}

To view supplementary material for this article, please visit https:/doi.org/ 10.1017/Soo47279417000782

\section{Acknowledgements}

The author is grateful for the financial support provided by the Research Training Group SOCLIFE, funded by Deutsche Forschungsgemeinschaft DFG (GRK1461). He thanks Stefano Sacchi, Achim Goerres and all the anonymous referees whose comments and suggestions greatly helped to improve the paper.

\section{Notes}

1 Despite its increase, social investment spending still takes a residual part of welfare budgets compared to old protection policies (most notably pensions). Vandenbroucke and Vleminckx's analysis goes up to the years 2005-2007, and includes 13 EU countries. Kuitto (2016) obtained similar results for the period 2000 to 2010, with spending data (as share of GDP) on 23 European countries, and data on benefit generosity for 14 countries.

2 Hudson and Kuhner (2009) and Van Vliet and Wang (2015) reached similar conclusions with bigger country samples, again on pre-crisis trends. Kuitto's (2016) results in respect to the resource competition hypothesis are more mixed.

3 The quote is originally taken from the work of the Austrian sociologist Rudolf Goldscheid, 'Staatssozialismus und Staatskapitalismus', as restated by Josef Schumpeter: 'The budget is the skeleton of the state stripped of all misleading ideologies'.

4 For example, parental leaves can be seen both as protection, insofar as they consist of out-ofwork benefits which suspend (and in some cases can even hurt) labour market participation, and as investment, in that they aim to reconcile work and family life, providing an incentive to have children in the European context of low fertility.

5 The SIWE dataset is available from the author's website (https://sronchi.wordpress.com/ siwe-data-set/). The STATA syntax to replicate the results can be sent upon request.

6 As discussed in De Deken (2014), the use of gross instead of net spending could overestimate social protection expenditure in countries which tax benefits (e.g. Nordic countries), while underestimating the extent of welfare effort when this largely relies on tax breaks (e.g. UK and Ireland, but also many continental and Southern EU countries for child allowances). In-work tax credits are included in the SIWE dataset.

7 In the years from 2000 to 2008 , with very few exceptions, the economies of all member states grew. The average EU-28 annual real GDP growth reached its peak in 2006 with +3.4 percentage points over the previous year. In 2008 growth slowed down. In 2009, all EU-28 economies (with the exception of Poland) shrank considerably, with an average of -4.4 negative GDP growth. In the following two years, overall, the feeble recovery did not compensate for the ground lost, and the recession struck again in 2012 (Eurostat online database, accessed February 2017). 
8 The most fitting example for the excessive business cycle-sensitivity of spending-over-theGDP figures is that of unemployment benefits: the numerator (spending on benefits) tends to react counter-cyclically, increasing during recessions as a consequence of the increased number of claimants. In contrast, the denominator (GDP) decreases when the economy falls into recession. This leads to an overestimation of budgetary welfare effort in times of economic crisis, that is, the scope of this inquiry.

9 Contrary to Vandenbroucke and Vleminckx (2011), we do not compare BWE indicators with GDP per capita. This would make those indicators vulnerable to the same pitfalls discussed above for spending-over-the-GDP measures (for example, BWE could become higher in Greece just because the denominator - GDP per capita - goes down). Spending in volumes expressed in PPS provides the same degree of cross-country comparability.

\section{References}

Adema, W. and Ladaique, M. (2009), 'How Expensive is the Welfare State?: Gross and Net Indicators in the OECD Social Expenditure Database (SOCX)', OECD Social, Employment and Migration Working Papers.

Ahn, S.H. and Kim, S.W. (2015), 'Social investment, social service and the economic performance of welfare states', International Journal of Social Welfare, 24, 2, 109-119.

Armingeon, K. (2012), 'The politics of fiscal responses to the crisis of 2008-2009', Governance, $25,4,543-565$.

Armingeon, K. (2013), 'Breaking with the past? Why the Global Financial Crisis led to austerity policies but not to modernization of the welfare state', in C. Pierson and F.G. Castles (eds.), The Welfare State Reader (3rd edn.), Oxford: Blackwell, 214-26.

Beramendi, P., Häusermann, S., Kitschelt, H. and Kriesi, H. (2015), The Politics of Advanced Capitalism, Cambridge: Cambridge University Press.

Bouget, D., Frazer, H., Marlier, E., Sabato, S. and Vanhercke, B. (2015), 'Social Investment in Europe. A study of national policies', Brussels: European Commission: DG Employment, Social Affairs and Inclusion.

Breunig, C. and Busemeyer, M.R. (2012), 'Fiscal austerity and the trade-off between public investment and social spending', Journal of European Public Policy, 19, 6, 921-938.

Cantillon, B. (2011), 'The paradox of the social investment state: growth, employment and poverty in the Lisbon era', Journal of European Social Policy, 21, 5, 432-449.

Castles, F.G. (2009), 'What Welfare States Do: A Disaggregated Expenditure Approach', Journal of Social Policy, 38, 1, 45-62.

Clasen, J. and Siegel, N.A. (2007), Investigating welfare state change: the 'dependent variable problem' in comparative analysis, Cheltenham: Edward Elgar Publishing.

De Deken, J. (2014), 'Identifying the skeleton of the social investment state: defining and measuring patterns of social policy change on the basis of expenditure data', in B. Cantillon and F. Vandenbroucke (eds.), Reconciling Work and Poverty Reduction, 260-285.

Deeming, C. and Smyth, P. (2015), 'Social investment after neoliberalism: policy paradigms and political platforms', Journal of social policy, 44, 2, 297-318.

Diamond, P. and Liddle, R. (2012), 'Aftershock: the post-crisis social investment welfare state in Europe', in N. Morel, B. Palier and J. Palme (eds.), Towards a Social Investment Welfare State?, Bristol: Policy Press, 91-116.

Esping-Andersen, G. (1990), The three worlds of welfare capitalism, Cambridge: Polity Press.

Esping-Andersen, G., Hemerijck, A., Gallie, D. and Myles, J. (2002), Why we need a new welfare state, Oxford: Oxford University Press.

European Commission (2013a), Investing in children: breaking the cycle of disadvantage, COM (2013) 788 final.

European Commission (2013b), 'Social protection budgets in the crisis in the EU', Luxembourg: Publications Office of the EU. 
European Commission (2013c), Strengthening the social dimension of the Economic and Monetary Union. COM (2013) 83 final.

European Commission (2013d), Towards Social Investment for Growth and Cohesion - including implementing the European Social Fund 2014-2020, COM (2013) 83 final.

Ferragina, E. and Seeleib-Kaiser, M. (2011), 'Thematic Review: Welfare regime debate: past, present, futures?', Policy \& Politics, 39, 4, 583-611.

Hemerijck, A. (2013), Changing welfare states, Oxford: Oxford University Press.

Hudson, J. and Kuhner, S. (2009), 'Towards productive welfare? A comparative analysis of 23 OECD countries', Journal of European Social Policy, 19, 1, 34-46.

Huo, J., Nelson, M. and Stephens, J.D. (2008), 'Decommodification and activation in social democratic policy: resolving the paradox', Journal of European Social Policy, 18, $1,5-20$.

Jenson, J. (2012), 'Redesigning citizenship regimes after neoliberalism. Moving towards social investment', in N. Morel, B. Palier and J. Palme (eds), Towards a Social Investment Welfare State?, Bristol: Policy Press, 61-90.

Jenson, J. (2017), 'Modernising the European Social Paradigm: Social Investments and Social Entrepreneurs', Journal of Social Policy, 46, 1, 31-47.

Kuitto, K. (2016), 'From social security to social investment? Compensating and social investment welfare policies in a life-course perspective', Journal of European Social Policy, $26,5,442-459$.

Kvist, J. (2013), 'The post-crisis European social model: developing or dismantling social investments?', Journal of International and Comparative Social Policy, 29, 1, 91-107.

León, M. and Pavolini, E. (2014), “Social Investment" or Back to "Familism": The Impact of the Economic Crisis on Family and Care Policies in Italy and Spain', South European Society and Politics, 19, 3, 353-369.

Mertens, D. (2017), 'The New Welfare State under Fiscal Strain: Austerity Gridlocks and the Privatization of Risks', in A. Hemerijck (ed.), The Uses of Social Investment, Oxford: Oxford University Press, 77-88.

Morel, N., Palier, B. and Palme, J. (2012), Towards a social investment welfare state?: ideas, policies and challenges, Bristol: Policy Press.

Natali, D. and Vanhercke, B. (2015), 'Social Policy in the European Union: State of Play 2015', Sixteenth annual report, ETUI - OSE.

Nikolai, R. (2012), 'Towards social investment? Pattern of public policy in the OECD world', in N. Morel, B. Palier and J. Palme (eds.), Towards a Social Investment Welfare State?, Bristol: Policy Press, 91-116.

Nolan, B. (2013), 'What use is "social investment"?', Journal of European Social Policy, 23, 5, 459-468.

Pavolini, E., León, M., Guillén, A.M. and Ascoli, U. (2015), From austerity to permanent strain? The EU and welfare state reform in Italy and Spain', Comparative European Politics, 13, 1, $56-76$.

Petmesidou, M. and Guillén, A.M. (2014), 'Can the Welfare State as We Know It Survive? A View from the Crisis-Ridden South European Periphery', South European Society and Politics, 19, 3, 295-307.

Pierson, P. (2011), 'The welfare state over the very long run', ZeS-Arbeitspapier, No. 02/2011, https://www.econstor.eu/dspace/handle/10419/46215 (accessed September 2017).

Ronchi, S. (2016), 'The Social Investment Welfare Expenditure data set (SIWE): a new methodology for measuring the progress of social investment in EU welfare state budgets', GK-SOCLIFE Working Paper Series, No. 16-2016, http://www.soclife.uni-koeln.de/sites/ gk_soclife/pdf/Working_papers/SOCLIFE_WP17.pdf (accessed December 2017).

Streeck, W. and Mertens, D. (2011), 'Fiscal austerity and public investment: Is the possible the enemy of the necessary?', MPIfG discussion paper No. 11/12.

Taylor-Gooby, P. (ed.) (2004), New risks, new welfare: the transformation of the European welfare state, Oxford, New York: Oxford University Press. 
Vaalavuo, M. (2013), 'The redistributive impact of "Old" and "New" social spending', Journal of Social Policy, 42, 3, 513-539.

Vandenbroucke, F. and Vleminckx, K. (2011), 'Disappointing poverty trends: is the social investment state to blame?', Journal of European Social Policy, 21, 5, 450-471.

Vandenbroucke, F., Hemerijck, A. and Palier, B. (2011), 'The EU needs a social investment pact', Observatoire Social Européen, Opinion Paper No. 5.

Van Kersbergen, K. and Hemerijck, A. (2012), 'Two decades of change in Europe: the emergence of the social investment state', Journal of Social Policy, 41, 3, 475-492.

Van Kersbergen, K., Vis, B. and Hemerijck, A. (2014), 'The Great Recession and Welfare State Reform: Is Retrenchment Really the Only Game Left in Town?', Social Policy \& Administration, 48, 7, 883-904.

Van Vliet, O. and Wang, C. (2015), 'Social Investment and Poverty Reduction: A Comparative Analysis across Fifteen European Countries', Journal of Social Policy, 44, 3, 611-638.

Wilkerson, J.D. (2003), 'The political economy of health in the United States', Annual Review of Political Science, 6, 1, 327-343. 